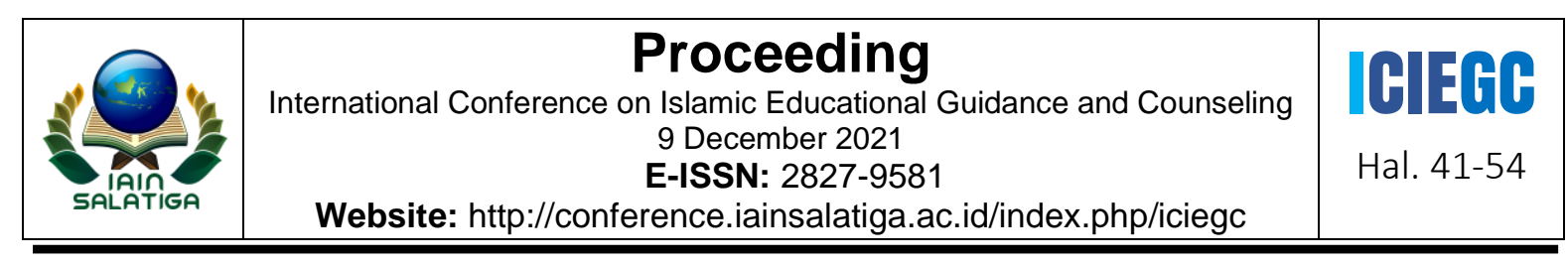

\title{
INTEGRASI BIMBINGAN AGAMA DAN BIMBINGAN VOKASIONAL DALAM MENUMBUHKAN ADVERSITY QUOTIENT BAGI REMAJA
}

\author{
Sri Maullasari ${ }^{1}$, Marisa Nur Indah ${ }^{2}$, Ema Hidayanti ${ }^{3}$ \\ ${ }^{1}$ Universitas Negeri Semarang \\ ${ }^{2,3}$ UIN Walisongo Semarang
}

\begin{tabular}{l}
\hline \hline Informasi Artikel \\
\hline Penulis Korespondensi: \\
Sri Maullasari, \\
Email: \\
maullasari174@gmail.com
\end{tabular}

\begin{abstract}
Individual success in overcoming problems has a role in the adversity quotient. Adversity quotient can be trained through religious guidance, namely with faith and spiritual intelligence. Those related to vocational guidance are talent, performance, productivity and creativity. Based on this, this research is to describe the integration of religious guidance and vocational guidance in growing adversity quotient for adolescents in Doro Village, Doro District, Pekalongan Regency. The research method in this research is descriptive qualitative. As for this research, the techniques used are observation, interview and documentation techniques. Religious guidance and vocational guidance in fostering an adversity quotient for adolescents in Doro Village, Doro District, Pekalongan Regency are implemented by establishing four main dimensions, (1) Self-control (Control), (2) Origin and self-recognition (Origin and Ownership, (3) Reach, (4) Endurance. These four dimensions are able to have an influence on the formation of an adversity quotient, namely through strengthening religious beliefs, strengthening spiritual intelligence, increasing performance, increasing creativity, and increasing productivity. the existence of religious guidance and vocational guidance is able to boost the adversity quotient of adolescents.
\end{abstract}

Keyword: Religious guidance; vocational guidance; adversity question; youth

\begin{tabular}{l}
\hline ABSTRAK \\
\hline Kesuksesan individu dalam mengatasi masalah terdapat sebuah peran \\
adversity quotient. Adversity quotient mampu dilatih melalui \\
bimbingan agama yaitu dengan keyakinan dan kecerdasan spiritual. \\
Adapun yang terkait dengan bimbingan vokasional adalah bakat, \\
kinerja, produktivitas dan kreativitas. Berdasarkan hal tersebut, \\
penelitian ini untuk mendeskripsikan integrasi bimbingan agama dan \\
bimbingan vokasional dalam menumbuhkan adversity quotient bagi \\
remaja di Desa Doro, Kecamatan Doro, Kabupaten Pekalongan. \\
Metode penelitian dalam penelitian ini bersifat kualitatif deskriptif. \\
Adapun dalam penelitian ini, teknik yang digunakan adalah teknik \\
observasi, wawancara dan teknik dokumentasi. Bimbingan agama \\
dan bimbingan vokasional dalam menumbuhkan adversity quotient \\
bagi remaja di Desa Doro, Kecamatan Doro, Kabupaten Pekalongan \\
diimplemenasikan dengan membentuk empat dimensi utama, (1) \\
Kendali diri (Control), (2) Asal- usul dan pengakuan diri (Origin dan \\
Ownership, (3) Jangkauan (Reach), (4) Daya Tahan (Endurance). \\
Keempat dimensi tersebut mampu memberikan pengaruh bagi \\
pembentukan adversity quotient yaitu melalui penguatan keyakinan
\end{tabular}


agama, penguatan kecerdasan spiritual, peningkatan kinerja, peningkatan kreativitas, dan peningkatan produktivitas. Dengan demikian, adanya bimbingan agama dan bimbingan vokasional mampu untuk mendongkrak adversity quotient remaja.

Kata kunci: Bimbingan agama; bimbingan vokasional; adversity question; remaja

\section{PENDAHULUAN}

Kesuksesan adalah keingininan tentang pencapaian dan impian setiap remaja. Remaja yang sukses memiliki dorongan yang mendalam untuk berjuang, untuk maju, untuk meraih cita- cita dan mewujudkan impian mereka (Herawati et al., 2018). Masa remaja merupakan salah satu tahap perkembangan yang akan dilalui oleh setiap individu. (Fitri et al., 2018), masa remaja adalah masa di mana individu dapat mencapai pola mental, emosional, sosial, fisik, dan transformasional dari masa kanak-kanak menuju dewasa. Melalui fase ini terdapat masa pemberian kesempatan untuk tumbuh dalam berbagai dimensi.

Namun, keadaan di lapangan menunjukkan bahwa adanya ketidakmampuan remaja dalam mengatasi permasalahannya sendiri. Hal demikian akan mengantarkan mereka pada kondisi yang tidak seimbang antara harapan dan kenyataan (Aliza \& Oktafiani, 2021). Adapun fenomena yang terjadi di masyarakat khususnya Desa Doro, Kecamatan Doro, Kabupaten Pekalongan banyak remaja yang menganggur. Untuk itu, membutuhkan bimbingan bagi remaja yang tidak bersekolah agar mempunyai keterampilan yang bisa dikembangkan. Orang dengan adversity quotient merupakan orang yang memiliki motivasi tinggi pada dirinya, maka dari remaja perlu memiliki adversity quotient di dalam diri untuk memotivasi mereka dalam berkarir. Dunia kerja membutuhkan kesiapan mental fisik atau psikis yang baik (Utami \& Hudaniah, 2013). Selain itu, faktor adversity quotient dalam bimbingan agama juga dipengaruhi oleh kecerdasan spiritual (Agustin, 2001).

Sehingga bimbingan agama dan bimbingan vokasional sebagaimana menjadi penting bagi remaja untuk meningkatan adversity question. (Rafi, 2009) mengungkapkan bahwa adversity quotient dapat disebut dengan kecerdasan adversitas, atau kecerdasan mengubah kesulitan, tantangan dan hambatan menjadi sebuah peluang yang besar. Adversity Quotient memiliki empat dimensi pembentuk:(1) Control (Kendali), menggambarkan sejauh mana seseorang mampu untuk secara positif mempengaruhi situasi; (2) Ownership (Pengakuan), menggambarkan sejauh mana seseorang bertanggungjawab; (3) Reach (Ketercapaian), menggambarkan sejauh manakah seseorang membiarkan kesulitan masuk ke dalam bidang kerja dan kehidupannya yang lain; dan (4) Endurance (daya tahan), menggambarkan seberapa lama seseorang menganggap kesulitan akan berlangsung (Nurvita, 2018). 
Sebagaimana penelitian oleh (Fitrianti \& Herdiyanto, 2016) bahwa adanya hubungan adversity question dengan motivasi berwirausaha. Kemudian dengan bantuan bimbingan agama juga mampu membentuk ketauhidan remaja yang lebih optimal (Khirzani et al., 2019). Alasan mendasar pengintegrasian bimbingan agama dan bimbingan vokasional adalah merujuk pada usaha membantu individu dalam memilih dan mempersiapkan suatu pekerjaan dan lebih menekankan pada kesesuaian bakat dan tuntutan (Kibtyah, 2015). Hal demikian harus berlandasan nilai-nilai agama (Amin, 2010) sebagaimana yang diyakini remaja. Sehingga diperlukanlah bimbingan agama dan bimbingan vokasional untuk membentuk adversity question remaja.

(Jung, 2018) penelitian ini menemukan bahwa pengalaman masa kecil yang merugikan tidak serta merta menyebabkan kesehatan mental yang buruk di masa dewasa. Lebih tepatnya, agama bertindak sebagai mekanisme penyeimbang yang dapat melindungi efek dari awal kemalangan di kemudian hari dalam perjalanan hidup. Kemudian menurut (Ie \& Visantia, 2013), keberhasilan suatu usaha dipengaruhi oleh motivasi. Salah satu faktor yang memunculkan motivasi dikenal dengan istilah adversity quotient atau yang biasa disingkat AQ (Stolz, 2000). Mempunyai motivasi tinggi merupakan salah satu hal yang dibutuhkan dalam adversity question melalui bimbingan vokasional.

Berdasarkan hasil studi pendahuluan yang penulis lakukan, maka menjadi menarik untuk mengkaji lebih dalam tentang bimbingan agama dan bimbingan vokasional. Di mana fokus penelitian ini adalah fokus terhadap adversity quotient bagi remaja. Adapun rumusan judul yang diangkat adalah "Bimbingan Agama dan Bimbingan Vokasional dalam Menumbuhkan Adversity Quotient bagi Remaja di Desa Doro, Kecamatan Doro, Kabupaten Pekalongan".

\section{METODE}

Penelitian ini bersifat kualitatif deskriptif, disebut penelitian deskriptif karena penelitian ini menekankan analisisnya pada hubungan penyimpulan deduktif, induktif, serta pada analisa terhadap dinamika hubungan antar fenomena yang datanya dengan menggunakan analisa ilmiah (Azwar, 2016). Adapun sumber data dalam penelitian ini diperolah melalui sumber data primer dan sumber data sekunder. Data primer adalah data yang diperoleh langsung dari subyek penelitian dengan mengenakan alat pengukuran atau alat pengambilan data langsung (Arintoko, 2006). Sedangkan data sekunder dalam penelitian ini akan diperoleh antara lain melalui berbagai literatur yang berkaitan dengan 
penelitian bimbingan agama dan bimbingan vokasional dalam menumbuhkan adversity quotient bagi remaja.

Adapun dalam penelitian ini, tehnik yang digunakan adalah tehnik observasi, wawancara dan teknik dokumentasi. Wawancara dilakukan untuk memperoleh data di lapangan dengan cara tanya jawab, melalui pendiri bimbingan agama dan bimbingan vokasional, guru pembimbing, dan remaja usia 19-22 tahun tidak bersekolah. Penelitian ini menggunakan observasi nonpartisipatif yang mana di sini peneliti hanya berperan mengamati saat kegiatan berlangsung. Adapun data yang dihasilkan dari metode dokumentasi ini adalah catatan, foto dan gambar yang berhubungan dengan bimbingan agama dan bimbingan vokasional di Desa Doro, Kecamatan Doro, Kabupaten Pekalongan.

Analisis data penelitian ini mengikuti model analisis Miles dan Huberman (Sugiyono yang terbagi dalam beberapa tahap; 1). Data Reduction untuk mendapatkan data sebanyak - banyaknya berdasarkan tujuan penelitian yang ditetapkan yaitu berkaitan dengan bimbingan agama dan bimbingan vokasional dalam menumbuhkan adversity quotient bagi remaja. 2). Data display adalah penyajian data. 3). Data Conclusion adalah untuk menjawab rumusan masalah penelitian dengan lebih terperinci.

\section{HASIL DAN BAHASAN}

\section{Hasil Penelitian}

Gambaran Desa Doro, Kecamatan Doro, Kabupaten Pekalongan

Desa Doro adalah sebuah kecamatan di kabupaten pekalongan, Provinsi Jawa Tengah. Desa Doro merupakan satu dari 14 Desa di kecamatan Doro Kab. Pekalongan yang berada pada ketinggian $350 \mathrm{dpl}$, kondisi geografisnya adalah pegunungan dan memiliki luas wilayah $68,45 \mathrm{~km}^{2}$. Sebagaimana wilayah Indonesia yang beriklim tropis, maka demikian juga dengan Desa Doro yang terdiri dari dua musim yaitu musim panas dan musim hujan. Desa Doro ini berjarak sekitar $15 \mathrm{~km}$ dari ibu kota Kabupeten Pekalongan ke arah timur. Pusat pemerintahnya berada di Desa Doro. Jumlah tenaga di Desa Doro, Kecamatan Doro, Kabupaten Pekalongan terdapat 5 orang guru. Adapun rinciannya adalah dalam tabel 1.

Tabel. 1 Keadaan Guru di Desa Doro, Kecamatan Doro, Kabupaten Pekalongan

\begin{tabular}{cl}
\hline No & \multicolumn{1}{c}{ Jabatan } \\
\hline 1 & $\begin{array}{l}\text { Pendiri bimbingan Agama dan bimbingan } \\
\text { vokasional, }\end{array}$ \\
\hline 2 & Guru bimbingan agama dan bimbingan vokasional \\
\hline 3 & Guru bimbingan agama dan bimbingan vokasional \\
\hline 4 & Guru bimbingan vokasional \\
\hline 5 & Guru bimbingan agama \\
\hline
\end{tabular}


Pemahaman agama bagi para remaja sangatlah penting sebagai bekal untuk masa depannya, dan sebagai pedoman untuk melakukan segala sesuatu yang pasti tidak keluar dari kaidah yang diajarkan oleh agamanya. Desa Doro, Kab. Pekalongan berupaya meningkatkan pengembangan pengetahuan agama remaja dengan melalui bimbingan agama. Bimbingan yang diberikan pada remaja dilihat dari beberapa aspek yaitu:

1. Tujuan Bimbingan Agama dan Bimbingan Vokasional.

Tujuan bimbingan agama di Desa Doro, Kecamatan Doro, Kabupaten Pekalongan untuk menuntun jalan manusia agar tidak gampang tersesat, serta dengan adanya bimbingan agama menjadikan tolak ukur bagi remaja. Adapun tujuan bimbingan vokasional untuk mengembangkan potensi yang ada pada diri remaja. Adanya bimbingan vokasional ini, bertujuan agar menjadi remaja yang terampil, dapat bekerja dengan mandiri dalam kehidupan dan tidak menjadi beban keluarga dan masyarakat.

2. Materi Bimbingan Agama dan Bimbingan Vokasional

Berdasarkan pernyataan dari guru bimbingan agama dan bimbingan vokasional serta remaja dapat disimpulkan bahwasanya materi yang disampaikan mulai dari ternak ayam, fotografi, pembuatan susu kedelai dan tehnik pemasaran prodak. Adanya diadakan berbagai macam materi yaitu untuk bisa menambah wawasan kepada remajanya, ataupun pengalaman dan nantinya bisa di praktikan dalam dunia kerja.

3. Metode Bimbingan Agama dan Bimbingan Vokasional

Pelakasanaan bimbingan agama dan bimbingan vokasional di Desa Doro, Kab.Pekalongan dalam melaksanakan bimbingan agama dilakukan melalui beberapa metode, yaitu metode langsung dan metode tidak langsung. Metode yang digunakan dalam bimbingan agama dan bimbingan vokasional menggunakan metode langsung yaitu yang dilakukan secara face to face antara guru bimbingan agama dan vokasional dengan remaja, sedangkan metode tidak langsung berupa media tulisan maupun lcd.

Bimbingan agama di Desa Doro Kecamatan Pekalongan Kabupaten Pekalongan adalah (1) memberikan perubahan tingkah laku dari yang kurang baik menjadi lebih baik, (2) Memberikan motivasi dalam mendorong manusia untuk melakukan suatu aktivitas dalam hidupnya berdasarkan nilai- nilai agama yang dipahaminya, (3) Sebagai penuntun jalan yang benar bagi manusia agar mereka tidak mudah tersesat, (4) Untuk membina moral atau mental seseorang kearah yang sesuai dengan ajaran Islam. 
Sedangkan tujuan bimbingan vokasional yaitu, (1) Untuk menanggulangi terjadinya angka pengangguran di masyarakat khususnya di Desa Doro, Kab. Pekalongan, (2) Menjadi remaja yang terampil, dapat bekerja dengan mandiri dalam kehidupan dan tidak menjadi beban keluarga dan masyarakat, (3) Bisa mengembangkan potensi yang dimiliki remaja. Adapun materi bimbingan agama berisikan tentang materi akidah, ibadah, dan akhlak. Selanjutnya, materi bimbingan vokasional berisikan tentang pembuatan susu kedelai, ternak ayam, fotografi, dan tehnik pemasaran prodak.

Bimbingan Agama dan Bimbingan Vokasional dalam Menumbuhkan Adversity Quotient bagi Remaja di Desa Doro, Kecamatan Doro, Kabupaten Pekalongan

Adapun fenomena yang terjadi di masyarakat khususnya Desa Doro, Kecamatan Doro, Kabupaten Pekalongan, ketika remaja dihadapkan pada kesulitan dan tantangan hidup kebanyakan remaja menjadi tidak berdaya. Mereka langsung menyerah, putus asa, gagal dan tidak dapat bertahan dari ujian ataupun kesulitan yang dihadapinya. Adapun untuk mengatasi permasalahan yang dihadapi dibutuhkan adversity quotient. Sukses tidaknya individu dalam kehidupan ditentukan oleh adversity quotient, dimana orang yang memiliki adversity quotient mereka tidak mudah menyerah dan mempunyai semangat tinggi untuk mencapai tujuan hidupnya. Adapun dalam adversity quotient terdapat empat dimensi utama yang menunjukan ketahanan seseorang dalam menghadapi masalah yaitu Control, Origin dan Ownership, Reach, dan yang terakhir Endurance yang bisa disingkat (CO2RE). Berikut ini merupakan penjelasan dari keempat dimensi tersebut:

1. Kendali diri (Control) (C)

Yaitu kemampuan individu dalam mempengaruhi secara positif terhadap situasi, serta mampu mengendalikan respon dalam situasi apapun individu dapat menyelesaikan. Adapun keyakinan agama yang kuat bagaimanapun sulitnya ujian, cobaan, dan halangan yang terdapat dalam hidup ini remaja dapat mengontrol emosi dengan baik atas permasalahan yang dihadapinya, sehingga bisa mengatasinya dengan tenang dan lebih baik. keyakinan dalam memeluk agama menjadi peranan penting dalam kehidupan manusia, karena dengan adanya keyakinan agama yang tertanam dalam diri kita, ketika kita mempunyai masalah ataupun kesulitan kita bisa selalu mengingat Allah SWT. Karena setiap masalah ataupun kesulitan selalu ada kemudahan jika kita bertahan dan percaya. Meyakini adanya rahmat yang diberikan oleh Allah merupakan suatu bentuk motivasi agar selalu melewati kesulitan- kesulitan yang dihadapi tanpa harus emosi. 
2. Asal -usul dan Pengakuan diri (Origin dan Ownership) $\left(\mathrm{O}_{2}\right)$

Yaitu suatu kemampun individu dalam menempatkan perasaan diinya dengan berani menanggung akibat dari situasi yang ada, sehingga menciptakan pembelajaran dalam melakukan perbaikan atas masalah yang terjadi. Dengan mengetahui dan mencari asalusul dari sebuah permasalahan maka dirinya dapat lebih termotivasi dan lebih jujur terhadap dirinya yaitu dengan cara mengakui dan mencari tahu terjadinya sebuah permasalahan. Orang yang memiliki kecerdasan spiritual akan mampu menyelesaikan permasalahan yang dihadapinya dengan melihat permasalahan itu dari sisi positifnya sehingga permasalahan dapat diselesaikan dengan baik dan cenderung melihat suatu masalah dari maknanya. Adanya kecerdasan spiritual ini memberikan makna dalam hidup umat manusia dengan nilai- nilai kebijakan yang bersumber dari agama dan diterapkan dalam kehidupan sehari- hari, sehingga bisa mendidik remaja menjadi manusia yang tentram, tabah, dan tawakal serta mampu memperdayakan kemampuannya secara maksimal untuk bisa menyelesaikan masalah yang ada pada hidupnya dengan bijaksana.

3. Jangkauan (Reach) (R)

Yaitu kemampuan individu dalam menjangkau dan membatasi masalah agar tidak menjangkau bidang- bidang lain. Kemampuan menjangkau terhadap masalah yang baik akan lebih mudah mendapatkan jalan keluar untuk menyelesaikan kesulitan atau permasalahan yang ada. Sehingga dengan kemampuan dan potensi yang dimilikinya dapat membuat jangkauan dan peluang yang cukup luas dalam meraih masa depan yang mereka cita- citakan. Begitu juga dengan masalah yang dihadapi oleh remaja yang mempunyai kelebihan khusus misalnya dalam hal produktivitas maupun kreativitas. Peran adversity quotient dalam kehidupan ditentukan oleh kemampuan cara kita merespon kesulitan dalam bentuk produktifitas maupun kreatifitas. Adanya kegigihan dan daya juang yang dimiliki remaja membuat remajanya lebih semangat dan hambatan maupun kesulitan terlewati dengan baik.

4. Daya tahan (Endurance) (E)

Adanya berbagai tuntutan pada remaja menjadikannya remaja tergerak untuk merespon tuntutan kerja agar tidak menjadi beban bagi dirinya. Banyak faktor dari adversity quotient yang berpengaruh terhadap kuat lemahnya daya tahan remaja dalam menghadapi kesulitan. Salah satunya adalah kinerja. Lingkungan mempengaruhi kinerja seseorang dalam menghadapi suatu situasi tertentu. Salah satu bentuk pengaruh 
lingkungan untuk meningkatkan adversity quotient adalah dukungan dari orang lain. Adanya dukungan tersebut dapat membuat remaja menjadi lebih kuat dan bertahan dalam menghadapi kesulitan.

Pernyataan dari guru bimbingan agama dan bimbingan vokasional serta remaja dapat disimpulkan bahwasanya bimbingan agama menjadi peranan penting dalam dunia kerja. Adanya bimbingan agama diharapkan dapat mencegah sikap- sikap menyimpang yang pada saat ini bermunculan di dunia kerja. Pada saat bekerja biasanya tidak hanya berjalan dengan mulus ataupun mudah, tetapi ada yang namanya tantangan atau tuntutan dalam bekerja. Adanya adversity quotient seorang yang mempunyai masalah ataupun kesulitan dalam bekerja bisa membuat bangkit lagi dari kesulitan yang dihadapi, sehingga kerjanya bisa menjadi semangat lagi.

Adapun bimbingan agama dan bimbingan vokasional dalam menumbuhkan adversity quotient terdapat empat dimensi utama yang menunjukkan ketahanan seseorang dalam menghadapi masalah. Adapun empat dimensi itu antara lain, Control, Origin dan Ownership, Reach, dan yang terakhir Endurance yang biasa disingkat (CO2RE). Adapun empat dimensi itu dipengaruhi oleh beberapa faktor dalam adversity quotient yang terkait bimbingan agama yaitu keyakinan dan kecerdasan spiritual. Adapun yang terkait dengan bimbingan vokasional adalah kinerja, produktivitas, dan kreativitas.

\section{Pembahasan}

Analisa Bimbingan Agama dan Bimbingan Vokasional

Berdasarkan data yang diperoleh dari penelitian pada kegiataan bimbingan agama dan bimbingan vokasional di Desa Doro, Kecamatan Pekalongan, Kabupaten Pekalongan, peneliti melakukan pengamatan langsung dan wawancara dengan remaja yang mengikuti bimbingan agama dan bimbingan vokasional. Dari hasil penelitian diketahui bahwa peran bimbingan agama sangat berpengaruh bagi remaja. Hal tersebut dikarenakan agama memiliki peran penting dalam kehidupan mereka. Agama memberikan sebuah kerangka moral, sehingga membuat seseorang mampu membandingkan tingkah lakunya. Agama dapat menstabilkan tingkah laku dan bisa menjelaskan mengapa dan untuk apa seseorang berada di dunia ini. Agama memberikan perlindungan rasa aman, terutama bagi remaja yang tengah mencari eksistensi dirinya (Mar'at, 2013).

Bimbingan agama yang diterapkan di Desa Doro, Kab. Pekalongan remajanya bisa mengalami perubahan dalam melakukan aktivitasnya sehari- hari. Pernyataan Khoirul dan Rendi sesuai yang disampaikan oleh N.a, remaja umur 22 tahun tidak bersekolah, kegiatan 
bimbingan agama ini memberikan dampak positif bagi remaja, ibadahnya jadi tambah lancar, bisa menghasilkan suatu perubahan, perbaikan, kesopanan, dan tingkah laku. Tujuan bimbingan agama adalah membina moral atau mental seseorang kearah yang sesuai dengan ajaran Islam, artinya setelah bimbingan agama itu terjadi, orang dengan sendirinya menjadikan agama sebagai pedoman dan pengendalian tingkah laku, sikap dan gerak dalam hidupnya. Hal ini diperkuat oleh (Arifin, 2009) tujuan bimbingan agama adalah untuk membantu seseorang supaya memiliki sumber pegangan agama dalam memecahkan masalah dengan kesadaran serta kemampuannya bersedia mengamalkan ajaran agamanya.

Sebagaimana penlitian oleh (Upadianti \& Indrawati, 2018) bahwa terdapat hubungan negatif yang signifikan antara adversity intelligence dengan kecemasan menghadapi dunia kerja. Semakin tinggi adversity intelligence individu semakin rendah tingkat kecemasan yang dialaminya. Dengan demikian membutuhkan bimbingan vokasional bagi remaja di Desa Doro, Kecamatan Doro, Kabupaten. Melalui diadakannya bimbingan vokasional yang bertujuan untuk mengembangkan potensi pada remaja, dengan begitu agar menjadi remaja yang terampil, dapat bekerja dengan mandiri dalam kehidupan dan tidak menjadi beban keluarga dan masyarakat. (Subroto, 1997) tujuan bimbingan vokasional ini membantu remaja agar memperoleh pemahaman diri dan pengarahan dalam proses mempersiapkan diri untuk bekerja dan berguna kelak dalm masyarakat

Berdasarkan pernyataan di atas dapat disimpulkan bahwa tujuan bimbingan agama dan bimbingan vokasional memberikan makna positif bagi remaja dalam menghadapi kehidupannya. Remajanya bisa jadi lebih semangat dalam menjalani kehidupan dan bisa mengalami banyak perubahan yang positif terkait ibadahnya, tingkah lakunya, maupun akhlaknya. Kemudian untuk memenuhi tuntutan kebutuhan karir remaja, perlu dilakukan pembaharuan layanan bimbingan dan konseling, terutama dalam pelayanan bimbingan vokasional pada tiga aspek penting yaitu; perencanaan, pelaksanaan dan evaluasi (Lestari, 2017).

Integrasi Bimbingan Agama dan Bimbingan Vokasional dalam Menumbuhkan Adversity Quotient bagi Remaja

Manusia akan memiliki semangat dalam dirinya, jika seluruh kegiatannya berpijak pada ajaran Islam, karena agama Islam memerintahkan agar bekerja keras dan tidak dibenarkan berputus asa. Pantang menyerah merupakan modal yang sangat besar didalam menghadapi segala macam tantangan. Sikap istiqomah, kerja keras, tangguh dan ulet akan tumbuh sebagai bagian dari diri kita. Pada Al- Qur'an terdapat beberapa penjelasan dan 
dorongan (motivasi) bagi manusia untuk terus berjuang di jalan Allah SWT dalam mengatasi kesulitan, dan senantiasa berlapang dada. Sedangkan bimbingan dan konseling sebagai layanan kemanusiaan adalah teosentris. Selain itu, manusia juga dikenal sebagai makhluk yang penghambaan dan khalifah yang dapat melakukan intervensi terhadap penyebab keselamatan manusia Hal ini didasari oleh Firman Allah dalam QS. Yusuf ayat 87, yang berbunyi:

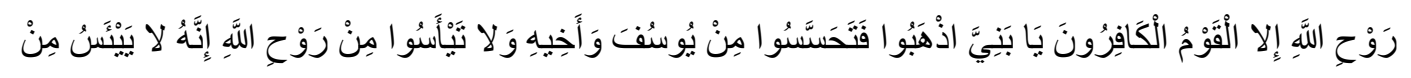
Artinya: “Hai anak-anakku, pergilah kamu, maka carilah berita tentang Yusuf dan saudaranya dan jangan kamu berputus asa dari rahmat Allah.

Sesungguhnya tiada berputus asa dari rahmat Allah, melainkan kaum yang kafir".

Ayat di atas menjelaskan bahwasanya, dalam hidup ini kita tidak boleh berputus asa, bahkan melarang untuk menyerah dalam menghadapi suatu tugas ataupun tantangan yang diberikan. Beban yang ada didalam kehidupan ini sesungguhnya merupakan suatu tantangan yang diberikan oleh Allah SWT kepada kita umat manusia agar selalu mengingat- Nya. Terdapat dalam kesulitan selalu ada kemudahan jika kita bertahan dan percaya. Maka kemampuan dalam bertahan terhadap kesulitan sesungguhnya Allah SWT telah menjelaskannya. Tidak berputus asa merupakan suatu bentuk dari kemampuan seseorang dalam menjalankan beban yang diberikan. Mempercayai adanya rahmat yang diberikan Allah merupakan suatu bentuk motivasi agar selalu melewati kesulitan- kesulitan yang dihadapi. Dengan demikian bahwa untuk meningkatkan kematangan karir bisa dipengaruhi adanya adversity question dan kesadaran diri (Kurniawan et al., 2020).

Adapun dalam menjalankan kehidupannya manusia biasanya menghadapi berbagai kesulitan. Seseorang mulai mengalami kesulitan untuk menentukan tujuan hidupnya, adakalanya seseorang merasakan jatuh bangun dalam menjalani kehidupan. Tetapi, kegagalan - kegagalan tersebut merupakan salah satu untuk mencapai keberhasilan. Tidak sedikit orang yang sulit untuk bangkit dari kegagalan tersebut. Seseorang yang memiliki kemampuan adversity quotient yang baik, maka ia berusaha keras untuk mencari jalan dan menghadapi kegagalan-kegagalan selama proses menyusun masa depannya. Stoltz, (2000) menggambarkan pendaki gunung dalam membagi konsep adversity quotient menjadi tiga kelompok yaitu pertama Climbers, kelompok yang suka mencari tantangan. Kedua, Quitters yaitu kelompok yang melarikan diri dari tantangan. Ketiga, Campers yaitu kelompok yang menyukai zona nyaman (Hartosujono, 2015). 
Melalui adversity quotient (Stoltz 2000) memberikan tehnik yang menjamin individu menjadi seseorang yang lebih kreatif serta dapat mengatasi ancaman dan kegagalan yang dialami. Adversity quotient dibutuhkan untuk mencapai kesuksesan dalam hidup, karena seseorang yang memiliki adversity quotient yang tinggi bisa sukses meskipun banyak hambatan menghadang. Mereka tidak langsung menyerah dan tidak membiarkan kesulitan menghancurkan impian dan cita -citanya. Adapun demikian itu peran adversity quotient sangat penting dalam kesuksesan seseorang.

Wardiana et al., (2014) menyatakan AQ merupakan salah satu kecerdasan yang dimiliki sesorang dalam mengatasi kesulitan dan merupakan sikap yang menunjukkan kemampuan orang untuk bisa mengatasi segala kesulitan serta hambatan saat seseorang mengalami kegagalan. AQ mampu memprediksi seseorang atau individu pada tampilan motivasi, pemberdayaan, kreativitas, produktivitas, pembelajaran, energi, harapan, kegembiraan, vitalitas dan kesenangan, kesehatan mental, kesehatan jasmani, daya tahan, fleksibilitas, perbaikan sikap, daya hidup dan respon terhadap perubahan (Romli, 2013).

Salah satu bentuk pengaruh lingkungan yang diharapkan untuk meningkatkan adversity quotient adalah dukungan dari orang lain. Adanya dukungan tersebut dapat membuat remaja menjadi lebih kuat dan bertahan dalam menghadapi kesulitan, yang akhirnya mendapatkan solusi dalam memecahkan masalah. Berdasarkan wawancara dengan Khoirul bahwa, lingkungan mempengaruhi kinerja seseorang dalam menghadapi suatu situasi tertentu. Hal ini menunjukkan bahwa secara tidak langsung lingkungan mempengaruhi bagaimana seseorang merespon dan menghadapi peristiwa yang dialaminya. Adanya dukungan orang lain dapat membuat remaja menjadi lebih kuat dan tahan menghadapi kesulitan yang dialaminya. Wawancara di atas senada yang disampaikan oleh Rendi, adanya dukungan dari orang lain remaja akan menjadi lebih kuat dan mampu mengatasi hambatan yang ada. Dukungan terhadap remaja bersumber dari dukungan keluarga dan teman sebaya. hubungan yang positif dan signifikan antara adversity quotient dan dukungan keluarga dengan kematangan karir remaja (Khusna et al, 2017).

Dukungan terhadap remaja bersumber dari dukungan keluarga, sekolah dan teman sebaya. Ketiga dukungan tersebut saling mendukung satu sama lain dan tidak dapat berdiri sendiri. Hubungan dengan keluarga, sekolah dan teman sebaya dipandang sebagai satu kesatuan yang membantu menghadapi tantangan. Hal ini diperkuat dengan hasil penelitian yang menyebutkan bahwa dukungan social memiliki peran penting bagi remaja. Rendahnya dukungan social yang diterima oleh para remaja tersebut diduga menjadi faktor yang 
menyebabkan gangguan pada penyesuaian diri yang positif pada kondisi yang terjadi (Puspasari et al., 2012).

Pembahasan di atas dapat disimpulkan bahwasanya bimbingan agama dan bimbingan vokasional dalam menumbuhkan adversity quotient bagi remaja terdapat empat dimensi yaitu, kendali diri (Control), asal- usul dan pengakuan diri (Origin dan Ownership), jangkauan (Reach), daya tahan (Endurance) yang mana dalam empat dimensi tersebut dipengaruhi oleh beberapa faktor yang terkait dengan bimbingan agama yaitu, keyakinan dan kecerdasan spiritual. Sedangkan yang terkait dengan bimbingan vokasional yaitu, kinerja, kreativitas, dan produktivitas. (Wutsqo et al., 2020) bahwa terdapat sumbangan efektif antara konsep diri dengan kematangan vokasional yaitu ditandai dengan semakin tinggi konsep diri maka semakin tinggi kematangan karir.

\section{KESIMPULAN}

Bimbingan agama dan bimbingan vokasional dalam menumbuhkan adversity quotient bagi remaja di Desa Doro, Kecamatan Doro, Kabupaten Pekalongan yaitu bimbingan agama dan bimbingan vokasional mampu membentuk empat dimensi utama, (1) Kendali diri (Control), (2) Asal- usul dan pengakuan diri (Origin dan Ownership, (3) Jangkauan (Reach), (4) Daya Tahan (Endurance). Yang mana empat dimensi itu sama- sama memberikan pengaruh bagi pembentukan adversity quotient yaitu melalui penguatan keyakinan agama, penguatan kecerdasan spiritual, peningkatan kinerja, peningkatan kreativitas, dan peningkatan produktivitas.

\section{DAFTAR RUJUKAN}

Agustin, A. G., (2001). Rahasia Sukses Membangun Kecerdasan Emosi dan Spiritual (ESQ). Jakarta: Arga Wijaya Persada.

Aliza, N. F., \& Oktafiani, L. (2021). Pengaruh Kecerdasan Emosi Terhadap Efikasi Diri Dan Adversity Quotient Remaja. Ristekdik: Jurnal Bimbingan dan Konseling, 6(1), 87. https://doi.org/10.31604/ristekdik.2021.v6i1.87-95

Amin, S.M. (2010). Bimbingan dan Konseling Islam. Jakarta: AMZAH.

Arifin, I. Z. (2009). Bimbingan Penyuluhan Islam (Pengembangan Dakwah Melalui Psikoterapi Islam). Jakarta: PT Raja Grafindo Persada.

Azwar, Saifuddin. (2016). Metode Penelitian. Yogyakarta: Pustaka Pelajar

Arintoko, S. (2006). Prosedur Penelitian Suatu Pendekatan Praktik. Jakarta: PT. Rineka Cipta.

Fitrianti, E. I., \& Herdiyanto, Y. K. (2016). Hubungan Adversity Quotient dengan Motivasi Berwirausaha pada Mahasiswa Universitas Udayana yang Mengikuti Program Mahasiswa Wirausaha. Jurnal Psikologi Udayana, 3(2), 2016. https://doi.org/10.24843/JPU.2016.v03.i02.p13 
Hartosujono. (2015). Perilaku Adversity Quotient Mahasiswa di Tinjau dari Locus Of Control. Jurnal Sosiohumaniora. DOI: https://doi.org/10.30738/sosio.v1i1.519

Herawati, I., Nugroho, S., \& Arief, Y. (2018). Adversity Quotient Pada Profesor. An-Nafs: Jurnal Fakultas $\quad$ Psikologi. $12(1), \quad$ 43-56. https://journal.uir.ac.id/index.php/annafs/article/view/2026.

Ie, M \& Visantia, E. (2013). Pengaruh efikasi diri dan motivasi terhadap keberhasilan usaha pada pemilik toko pakaian di Pusat Grosir Metro Tanah Abang Jakarta. Jurnal Manajemen. 13(2). 1-14. https://doi.org/10.28932/jmm.v13i1.139

Jung, J. H. (2018). Childhood Adversity, Religion, and Change in Adult Mental Health. Research on Aging, 40(2), 155-179. https://doi.org/10.1177/0164027516686662

Khirzani, N., Effendi, D. I. I., \& Mujib, A. (2019). Bimbingan Agama dalam Meningkatkan Pemahaman Ketauhidan Remaja. Irsyad: Jurnal Bimbingan, Penyuluhan, Konseling, dan Psikoterapi Islam, 7(3), 331-350. https://doi.org/10.15575/irsyad.v7i3.168.

Khusna, N., Karyanta N.A., \& Setyanto A.T. (2017). Hubungan antara Adversity Quotient dan Dukungan Keluarga dengan Kematangan Karir Remaja Yatim di SMA di $\begin{array}{llll}\text { Surakarta. } & \text { Wurnal }\end{array}$ DOI: https://doi.org/10.13057/wacana.v9i1.101

Kibtyah, M. (2015). Bimbingan \& Konseling Karir dalam Perspektif Islam, Cet. 1. Semarang: CV. Karya Abadi Jaya.

Kurniawan, W., Daharnis, D., \& Karneli, Y. (2020). Contribution of Adversity Quotient, Self Awareness and Demographic Factors to Student Career Maturity. International Journal of Research in Counseling and Education, 4(1), 70-75. https://doi.org/10.24036/00261za0002

Lestari, I. (2017). Meningkatkan Kematangan Karir Remaja Melalui Bimbingan Karir Berbasis Life Skills. Jurnal Konseling GUSJIGANG. 3(1), 17-27 DOI: http://dx.doi.org/10.24176/jkg.v3i1.859.

Mar'at, S. (2013). Psikologi Perkembangan. Bandung: PT Remaja Rosdakarya

Nurvita, D. N. (2018). Potret Adversity Quotient pada Mahasiswa Bimbingan Konseling Islam. Journal An-Nafs: Kajian Penelitian Psikologi, 3(2), 162-182. https://doi.org/10.33367/psi.v3i2.622

Puspasari, D. A., Kuwato, T., \& Wijaya, H. E. (2012). Dukungan Sosial Dan Adversity Quotient Pada Remaja Yang Mengalami Transisi Sekolah. Psikologika: Jurnal Pemikiran dan Penelitian Psikologi, 17(1), 69-76. https://doi.org/10.20885/psikologika.vol17.iss1.art8

Rafi, S. (2009). Psikologi Islam: Tuntunan Jiwa Manusia Modern. Jakarta: Rajawali Pers.

Romli, R. A. (2013). Perbedaan pola pikir kewirausahaan dan adversity quotient pada mahasiswa psikologi universitas negeri malang yang berorientasi terhadap pencipta lapangan kerja dan pencari kerja. Jurnal Psikologi Universitas Negeri Malang. 1(1). 1-12. http://karya-ilmiah.um.ac.id/index.php/Fak-Psikologi/article/view/26351

Stoltz, P. G. (2000). Adversity Quotient: Mengubah Hambatan Menjadi Peluang. Jakarta: PT. Grasindo.

Subroto, S. (1997). Proses Belajar Mengajar di Sekolah. Jakarta: Rineka Cipta.

Upadianti, L. P. S., \& Indrawati, E. S. (2018). Hubungan Antara Adversity Intelligence Dengan Kecemasan Menghadapi Dunia Kerja Pada Mahasiswa Tingkat Akhir Departemen Teknik Perencanaan Wilayah Kota Dan Teknik Elektro Universitas $\begin{array}{llll}\text { Diponegoro. Jurnal } & \text { Empati. } & \text { 11-20. }\end{array}$ https://ejournal3.undip.ac.id/index.php/empati/article/view/21840 
Utami, Y.G.D. \& Hudaniah. (2013). Self Efficacy dengan Kesiapan Kerja Siswa Sekolah Menengah Kejuruan. Jurnal Ilmiah Psikologi Terapan. 1(1). 40-52. https://doi.org/10.22219/jipt.v1i1.1356

Wardiana, I. A., Wiarta, I., \& Zulaikha, S. (2014). Hubungan adversity quotient (AQ) dan minat belajar dengan prestasi belajar matematika pada siswa kelas V SD di kelurahan pedungan. Jurnal Mimbar Universitas Pendidikan Ganesha. 2(1). 1-11. DOI: http://dx.doi.org/10.23887/jjpgsd.v2i1.3026

Wutsqo, B. U., Rizky, D. M., \& Hidayat, D. R. (2020). Hubungan Konsep Diri dengan Kematangan Vokasional Pada Siswa SMK. Jurnal Ilmiah Bimbingan Konseling Undiksha, 11(1), 54-60. http://dx.doi.org/10.23887/jibk.v10i2 